$A L .11781=2$

\section{Fish \& Wilditie Division}

RESOURCE DATA AND SPECIES AT RISK SECION

\title{
RESEARCHING AMPHIBIAN NUMBERS IN ALBERTA (RANA): 2003 PROVINCIAL REPORT
}

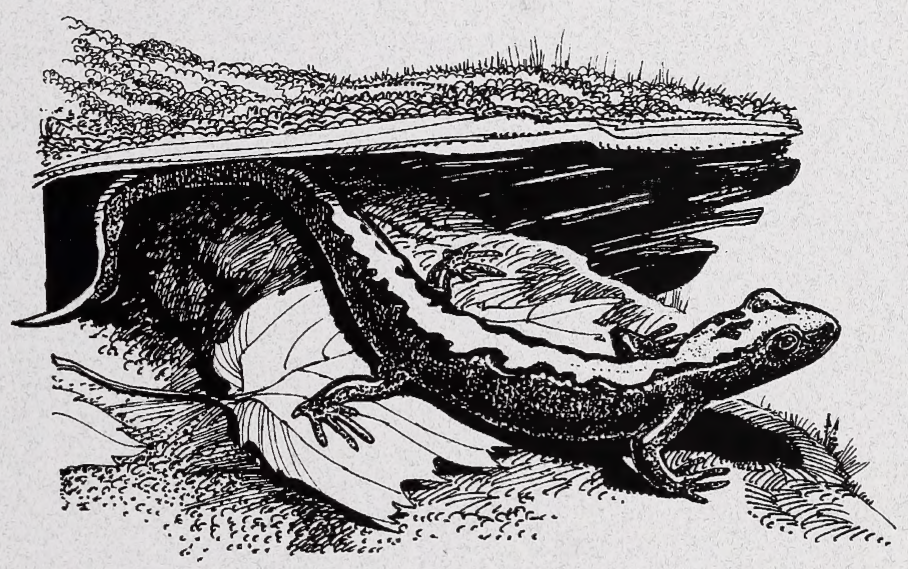





\title{
Researching Amphibian Numbers in Alberta (RANA)
}

\section{Provincial Report}

\author{
Lisa Wilkinson \\ and \\ Kent Kempin
}

Alberta Species at Risk Report No. 83

2004

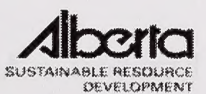

Fish \& Wildlife 
Publication No.: I/143

ISBN No. 0-7785-2969-X (Printed Edition)

ISBN No. 0-7785-2970-3 (On-line Edition)

ISSN: 1496-7219 (Printed Edition)

ISSN: 1496-7146 (On-line Edition)

Illustration: Brian Huffman

For copies of this report, contact:

Information Centre - Publications

Alberta Environment / Alberta Sustainable Resource Development

Main Floor, Great West Life Building

9920108 Street

Edmonton, Alberta, Canada T5K 2M4

Telephone (780) 422-2079

OR

Visit our website at:

http://www3.gov.ab.ca/srd/fw/riskspecies/

This publication may be cited as:

Wilkinson, L. and K. Kempin. 2004. Researching Amphibian Numbers in Alberta (RANA): 2003 provincial summary. Alberta Sustainable Resource Development, Fish and Wildlife Division, Alberta Species at Risk Report No.83. Edmonton, AB. 


\section{DISCLAIMER}

The views and opinions expressed are those of the authors and do not necessarily represent the policies or positions of the Department or the Alberta Government. 
LIST OF TABLES

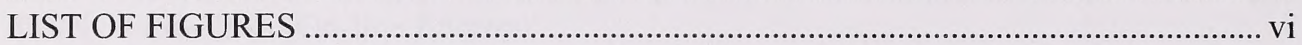

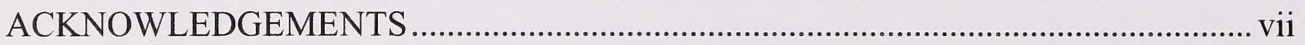

EXECUTIVE SUMMARY ….................................................................................

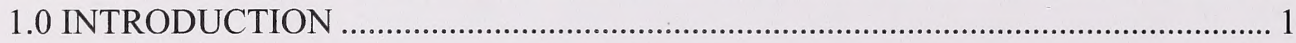

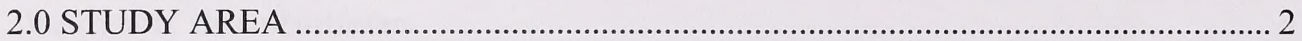

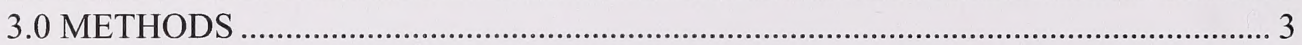

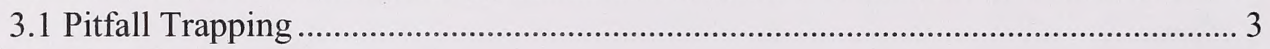

3.2 Shoreline Pond Surveys .................................................................................... 4

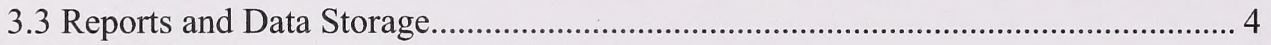

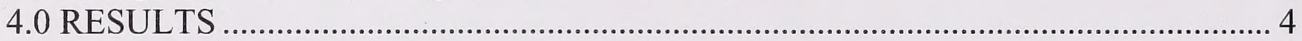

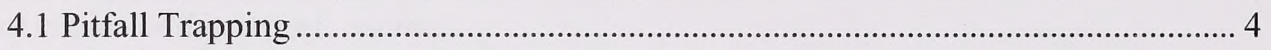

4.1.1 Spring Pitfall Trapping Session ................................................................... 5

4.1.2 Late Summer Pitfall Trapping Session ........................................................... 5

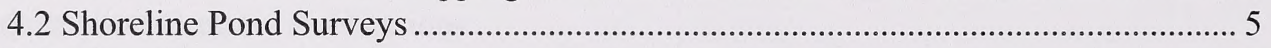

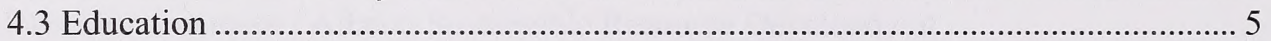

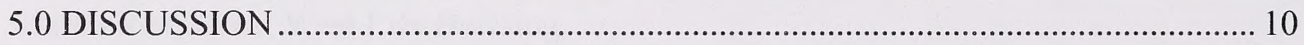

6.0 MANAGEMENT IMPLICATIONS AND FUTURE RESEARCH ….................... 11

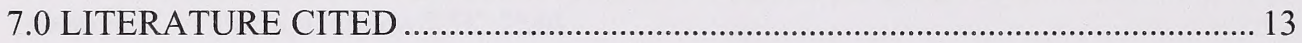




\section{LIST OF TABLES}

Table 1. Spring amphibian captures and morphological characteristics from Alberta RANA sites in 2003.

Table 2. Late summer amphibian captures and morphological characteristics from RANA sites in 2003.

Table 3. Amphibian species observations from all pond surveys in 2003. 9

Table 4. Summary of educational/interpretive presentations given to the public from all Alberta RANA sites in 2003.

\section{LIST OF FIGURES}

Figure 1. Alberta distribution of RANA sites........................................................ 2

Figure 2. Layout of fencing and pitfall traps (A), and close-up of pitfall trap design (B). 3 


\section{ACKNOWLEDGEMENTS}

The following agencies generously provided funding and/or support for this program:

Alberta Conservation Association

Alberta Sustainable Resource Development

Cypress Hills Provincial Park

Foothills Model Forest

Friends of Saskatoon Island Provincial Park

Heritage Association of Cypress Hills

Human Resources Development Canada (Student Career Placements)

Lesser Slave Lake Provincial Park

Saskatoon Island Provincial Park

University of Alberta, Biological Sciences Division

University of Calgary, Kananaskis Research Station

Weldwood of Canada Ltd., Hinton Division

The following people monitored the RANA sites and conducted educational programs, their commitment and hard work are greatly appreciated:

Cypress Hills - Jennell Rempel

Hinton - Stephen Hanus

Kananaskis - Selwyn Rose

Lesser Slave Lake Provincial Park - Sabrina Popp

Meanook Biological Field Station - Tara Booker and Kirsten Norris

Saskatoon Island Provincial Park - Theresa Augustyn

Kris Kendell provided technical and administrative support. A big thanks goes out to the numerous volunteers who provided much needed assistance in the field.

RANA has succeeded over the years through financial and in-kind support from a number of agencies, as well as the continued support of dedicated individuals. This program is a testament to the possibilities and kind of success that can occur when supportive individuals and agencies believe in a common goal. 


\section{EXECUTIVE SUMMARY}

Six RANA (Researching Amphibian Numbers in Alberta) sites were operated in 2003: Kananaskis (Bow Valley), Hinton (Athabasca Valley), Lesser Slave Lake Provincial Park, Saskatoon Island Provincial Park, Cypress Hills Provincial Park, and Meanook Biological Research Station.

Seven species were captured in 2003: boreal chorus frogs, boreal toads, long-toed salamanders, northern leopard frogs, tiger salamanders, wood frogs, and Columbia spotted frogs. Columbia spotted frogs and northern leopard frogs had not been captured previously in the RANA program. Shoreline pond surveys were conducted at 214 ponds within five RANA study areas, with an additional 29 pond surveys in Jasper National Park. Species observed, in order of decreasing abundance, were: wood frogs, long-toed salamanders, boreal toads, boreal chorus frogs, northern leopard frogs, tiger salamanders, and Columbia spotted frogs. No Canadian toads were observed, despite having study sites within their range. Regional and provincial summaries of amphibian morphological characteristics are provided in this report, along with summaries of capture rates for all species encountered at each of the RANA trapping ponds. Educational programs reached approximately 6,000 people. 
Digitized by the Internet Archive in 2016 


\subsection{INTRODUCTION}

Field data collection for the Researching Amphibian Numbers in Alberta (RANA) program was initiated in 1997 in response to the global decline of amphibians. RANA has two primary objectives: 1) collect long-term data on amphibian species populations in Alberta, and 2) provide public education on the importance of amphibians and wetland conservation. Two sites were operated in 1997, and since that time, an additional five monitoring sites were established, although not all sites can be operated every year.

There were six active sites in 2003: Lesser Slave Lake Provincial Park (est. 1997), Saskatoon Island Provincial Park (est. 1999), Meanook Research Station (est. 1997), Cypress Hills Provincial Park (est. 1999), Athabasca Valley (Hinton; est. 2000), and Bow Valley (Kananaskis; est. 1998). Beaverhill Lake is no longer operated as a RANA site due to logistical constraints.

The following species have been captured or observed in the RANA program: wood frogs (Rana sylvatica), boreal chorus frogs (Pseudacris maculata), Columbia spotted frogs (Rana luteiventris), northern leopard frogs (Rana pipiens), boreal toads (Bufo boreas), Canadian toads (Bufo hemiophrys), long-toed salamanders (Ambystoma macrodactylum), and tiger salamanders (Ambystoma tigrinum). The only two amphibian species that have not been observed during the RANA program are the great plains toad (Bufo cognatus) and the plains spadefoot toad (Spea bombifrons), both of which are found in the grassland natural region (Alberta Environmental Protection 1994), which is not currently represented. Only one Canadian toad has been captured since the establishment of the RANA program, in 1998 at Lesser Slave Lake.

Few of Alberta's amphibians are considered 'secure'. Of the species encountered in the RANA program, the northern leopard frog is 'threatened', the Canadian toad is 'data deficient' ('may be at risk'), and the long-toed salamander and Columbia spotted frog are 'sensitive' (Alberta Sustainable Resource Development 2000). Long-toed salamanders are the focal species in Hinton and Kananaskis due to the current provincial objective to monitor their population distribution and trends for at least five years. Additional details of the salamander program are in Wilkinson and Hanus (2003).

Public education has always been a fundamental component of the RANA program. Education takes the form of presentations, public event displays, guided hikes, school talks and other activities. Technical presentations are given to land-use managers (industry and government) and at biological conferences. In conjunction with RANA educational programs, the Alberta Amphibian Monitoring Program (AAMP) is promoted. This program encourages members of the public to record and submit amphibian observations throughout the province. An instruction manual, including identification photos and a tape of frog and toad calls, is also provided to interested individuals.

This document is a compilation of 2003 field results from each RANA site summarizing key findings. Individual field summary reports for 2003 have been developed for Hinton (Hanus 2004), Kananaskis (Rose 2004), Lesser Slave Lake Provincial Park (Kempin 2004), Saskatoon Island Provincial Park (Augustyn 2004), Cypress Hills Provincial Park (Rempel 2004), and Meanook Biological Research Station (Kempin 2004). 


\subsection{STUDY AREA}

The RANA program has sites distributed across Alberta (Figure 1) to represent a variety of natural regions (Alberta Environmental Protection 1994). Cypress Hills is located in a unique montane ecosystem within the grassland natural region, Kananaskis (Bow Valley) is located in the rocky mountain and foothills natural regions, the Hinton (Athabasca Valley) site is located in the foothills natural region, and the Meanook Biological Research Station, Lesser Slave Lake and Saskatoon Island Provincial Park sites are located in different parts of the boreal forest natural region. In addition, pond surveys were conducted in and around Jasper National Park, as part of the long-toed salamander monitoring program.

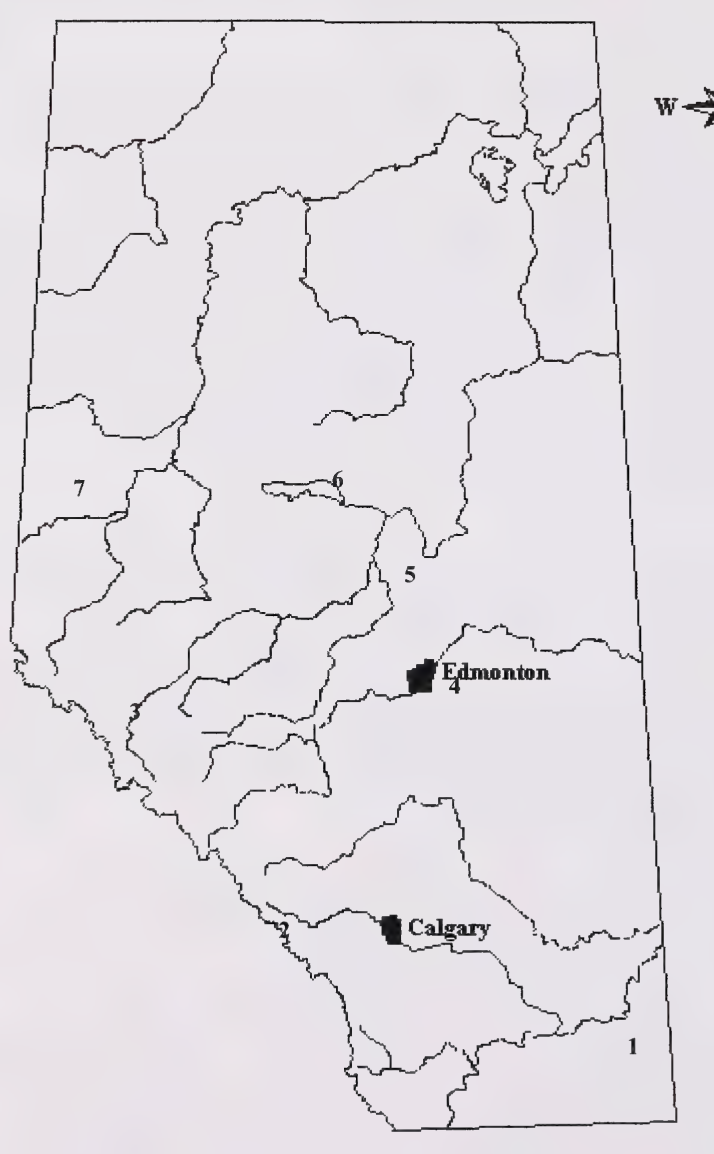

RANA Sites:

1. Cypress Hills Provincial Park

2. Kananaskis (Bow Valley)

3. Hinton (Athabasca Valley)

4. Beaverhill Lake

5. Meanook Biological Research Station

6. Lesser Slave Lake Provincial Park

7. Saskatoon Island Provincial Park

Figure 1. Alberta distribution of RANA sites. 


\subsection{METHODS}

Methods for surveying and capturing long-toed salamanders and other amphibians followed Pretzlaw et al. (2002), and are summarized below. Any variations to the methods are included in the individual site reports.

\subsection{Pitfall Trapping}

In each RANA survey area, there is one pond set up for pitfall trapping. The pond is completely or partially encircled with drift net fencing (Figure 2A). Pitfall traps are placed at $10 \mathrm{~m}$ intervals on either side of the fence. Theoretically, amphibians travelling to or from the pond to breed will be intercepted by the fence and travel along the barrier until they fall into a trap. Traps consist of two 6-inch plastic flower pots taped together, creating a 12-inch deep trap (Figure 2B). Traps are covered by a square of coroplast, a sturdy and water resistant plastic, held above the traps by 6-inch nails. Trap covers ensure that amphibians are protected from excessive exposure to sun, which can lead to desiccation, and prevent flooding from rainfall. The following items are placed in each trap: a sponge and/or moss, which is refreshed regularly to retain moisture; a rock that serves as a perch or hiding place; and a stick protruding past the top of the trap to allow small mammals to escape.

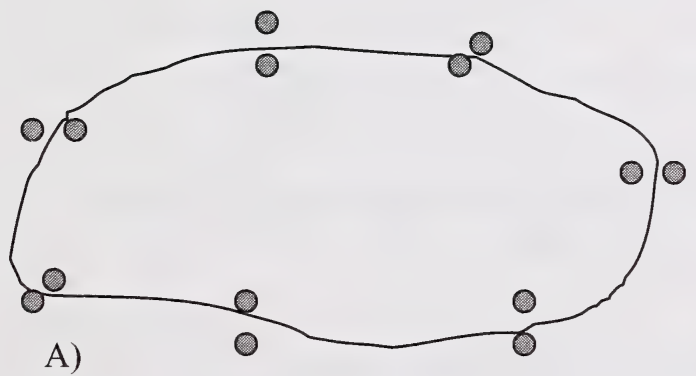

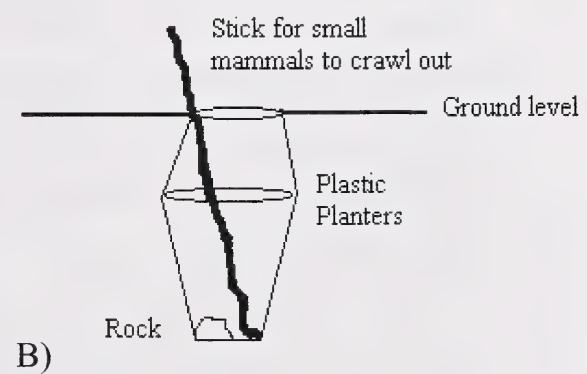

Figure 2. Layout of fencing and pitfall traps (A), and close-up of pitfall trap design (B).

Trapping schedules varied slightly between sites, but traps were generally set during the spring breeding season (May to early June), and late summer (August to early September) when young-of-the-year disperse from the ponds. The Meanook site was operated from July to mid-August for logistic reasons. Throughout the trapping sessions, traps were checked daily or every other day. Traps were generally closed during mid-summer when amphibian movement to and from ponds declined. Captured animals were identified to species, measured, weighed, and sex and age determinations were made when possible. Animals were released on the opposite side of the fence from which they were captured. Other morphological characteristics, such as presence of dorsal stripes and malformations were also recorded. Small individuals captured at the beginning of the season were presumed to be juveniles (young-of-the-year from the previous season). Age and sex differentiation was not possible for all species. Researchers used latex gloves when handling amphibians to avoid contaminating amphibians with oils or hand lotion. Animals being released away from the pond were moistened and placed in a sheltered 
location; extra care was taken on hot days, releasing amphibians early or late in the day to prevent desiccation. Environmental data were also collected, including air and water temperature, pond $\mathrm{pH}$, water depth, and other ambient conditions. At the Hinton RANA site, long-toed salamanders were marked with elastomer (a non-toxic latex) as part of an ongoing mark-recapture study (refer to Wilkinson and Hanus 2003 for details).

At the end of each trapping session all traps were closed by either pushing the coroplast cover flush to the ground and covering it with dirt and a rock, or by inverting traps, to ensure animals could not enter. Also, sections of fence were opened at several locations around the pond to allow animals to pass through.

\subsection{Shoreline Pond Surveys}

Pond surveys were conducted to identify presence of breeding amphibians through observations of eggs, larvae/tadpoles, young-of-the-year, or adults, as well as to hear vocalizations in the spring. Survey efforts were most intensive during spring egg-laying, although some ponds were visited later in the summer to look for presence of larvae and tadpoles.

Surveys were conducted by walking along the perimeter of a pond, or using transects for large and/or partially inaccessible water bodies, and looking for signs of amphibian presence. Surveys could not be conducted under excessively windy or rainy conditions because the surface of the water was disturbed. Similarly, care was taken not to disturb the surface of the water around the shoreline. Data recorded included number of salamander eggs, number of frog egg masses, and number of toad egg strings. For observations of larvae and tadpoles a specific count was made if possible, otherwise qualitative observations were made using estimates of few, moderate, or abundant (a similar system applies to vocalizations). Observations of adults were also recorded. Environmental data were collected as per pitfall trapping ponds, and GPS locations were recorded for all ponds surveyed.

At some sites, the length of survey distance was recorded, allowing for future calculations of number of eggs/meter, enabling relative abundance comparisons over time.

\subsection{Reports and Data Storage}

In addition to this summary report, a report was produced for each RANA site and distributed to local government offices, stakeholders, funding agencies, participants and volunteers, and other interested parties. All data have been electronically recorded and incorporated into the provincial government Biodiversity/Species Observation Database (BSOD).

\subsection{RESULTS}

\subsection{Pitfall Trapping}

Results from spring and late summer pitfall trapping sessions are provided in Table 1 and 2 , respectively. In addition, amphibian capture data from each RANA site since their establishment is provided in Appendix 1. 
Five of the six active RANA sites were open during the spring trapping session in 2003, and a total of five amphibian species were captured (Table 1). Wood frogs were the most numerous amphibian species captured during the spring trap session (287), with nearly $80 \%$ of those captures at Lesser Slave Lake Provincial Park. Long-toed salamanders were the second-most captured species in the spring (218) and were found only at the Hinton and Kananaskis sites, followed by boreal chorus frogs (49), boreal toads (36), and tiger salamanders (6). No one species was present at all trapping sites, but wood frogs were caught at every site except Cypress Hills Provincial Park.

\subsubsection{Late Summer Pitfall Trapping Session}

Five of the six active RANA sites were open during the late summer trapping session, with Meanook being operational for the early part of this period (July 4 - Aug. 12). A total of seven amphibian species were captured (Table 2). Of the species observed, wood frogs were the most numerous, primarily due to the large number of young-of-the-year captured at the Meanook site (1989). Other amphibian species captured, in decreasing order of abundance, were long-toed salamanders (173), boreal toads (91), northern leopard frogs (71), boreal chorus frogs (32), tiger salamanders (4), and Columbia spotted frogs $(1 ;)$.

\subsection{Shoreline Pond Surveys}

Pond surveys were conducted at a total of 216 ponds in Cypress Hills, Hinton, Kananaskis, Lesser Slave Lake, and Saskatoon Island (Table 3), with an additional 29 ponds in Jasper National Park. Wood frogs were the most ubiquitous species, observed at $49 \%$ of ponds surveyed. The highest amphibian species diversity, with four species, was shared between the Hinton, Kananaskis, and Saskatoon Island Provincial Park sites. In Cypress Hills, northern leopard frogs were present at $47 \%$ of ponds surveyed.

\subsection{Education}

Education took a variety of forms, including presentations, public displays, guided talks, children's activities, and newspaper/newsletter articles. Site specific amphibian presentations were developed for each RANA site, and posters of local amphibians were also created for some sites. An estimated total of 5969 people were informed about amphibians, RANA, the AAMP, and wetland conservation throughout the province (Table 4). Kananaskis had an active outreach program, using public events to reach large numbers of people, while Cypress Hills used a variety of media to reach people within and around the park. Saskatoon Island also reached a larger number of people through interpretative talks, and school talks were the focus of Hinton and Lesser Slave Lake educational programs. Details about presentations and activities are included in each RANA site report. 
(3)

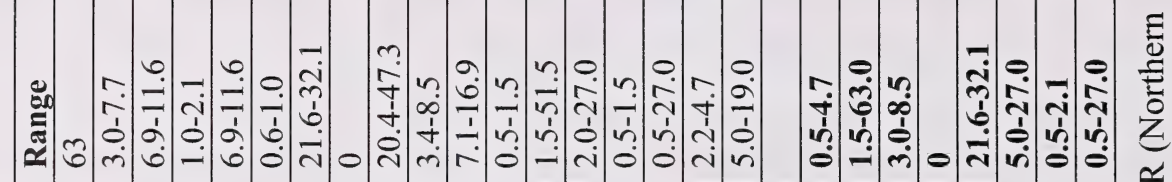

है

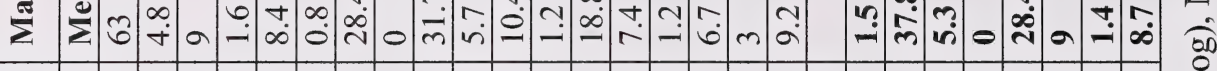

ชู

$\Xi$

$\stackrel{\infty}{\stackrel{\infty}{*}}$

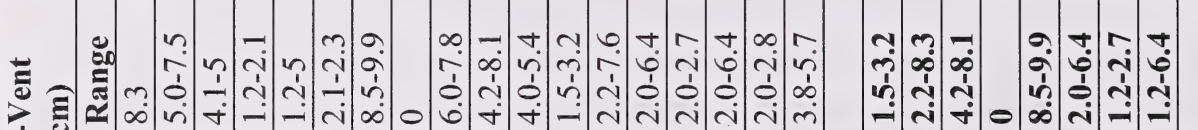

단

$\varangle$ 艺

Z

$\simeq$

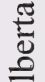

ص

j.

I - m

(5)

$\infty \underset{m}{\infty}$

의 0

$0-2$

t. 0.40 .0000

- n

\# F

ำ

诖

8

$\frac{2}{\underline{c}}$

$\delta^{\infty}$

i

30

(ิ)

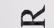

$?$

를

¿

क

\#

폴

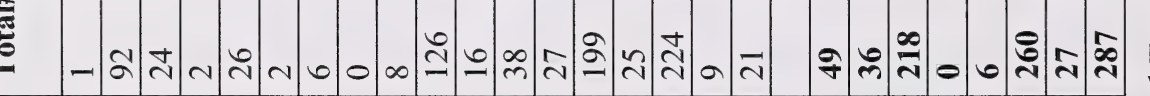

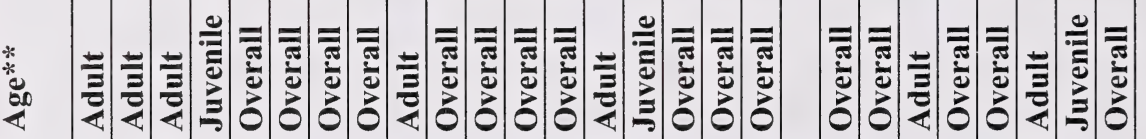

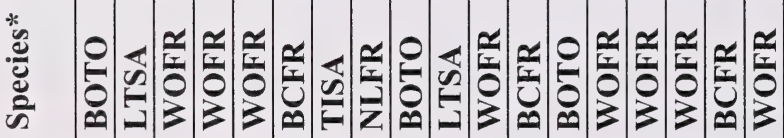

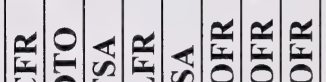

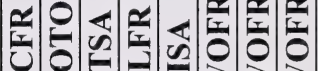

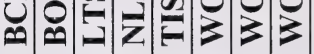

$\stackrel{\Xi}{\exists}$

约

-

ชิ

क
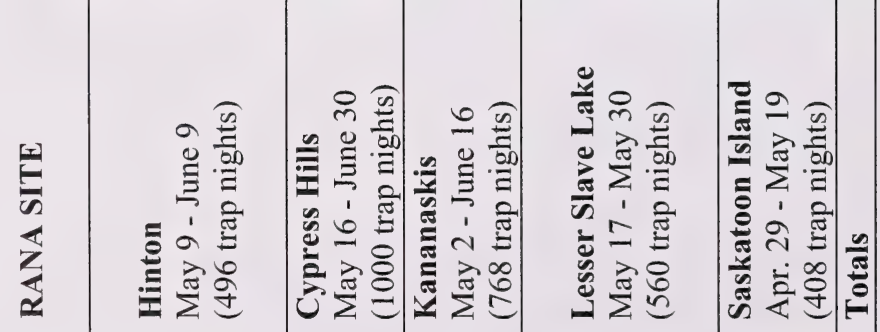

홀

난 3

纪

苛

एँ की

ธิ

든

졸

든 흥

$10 *$ 


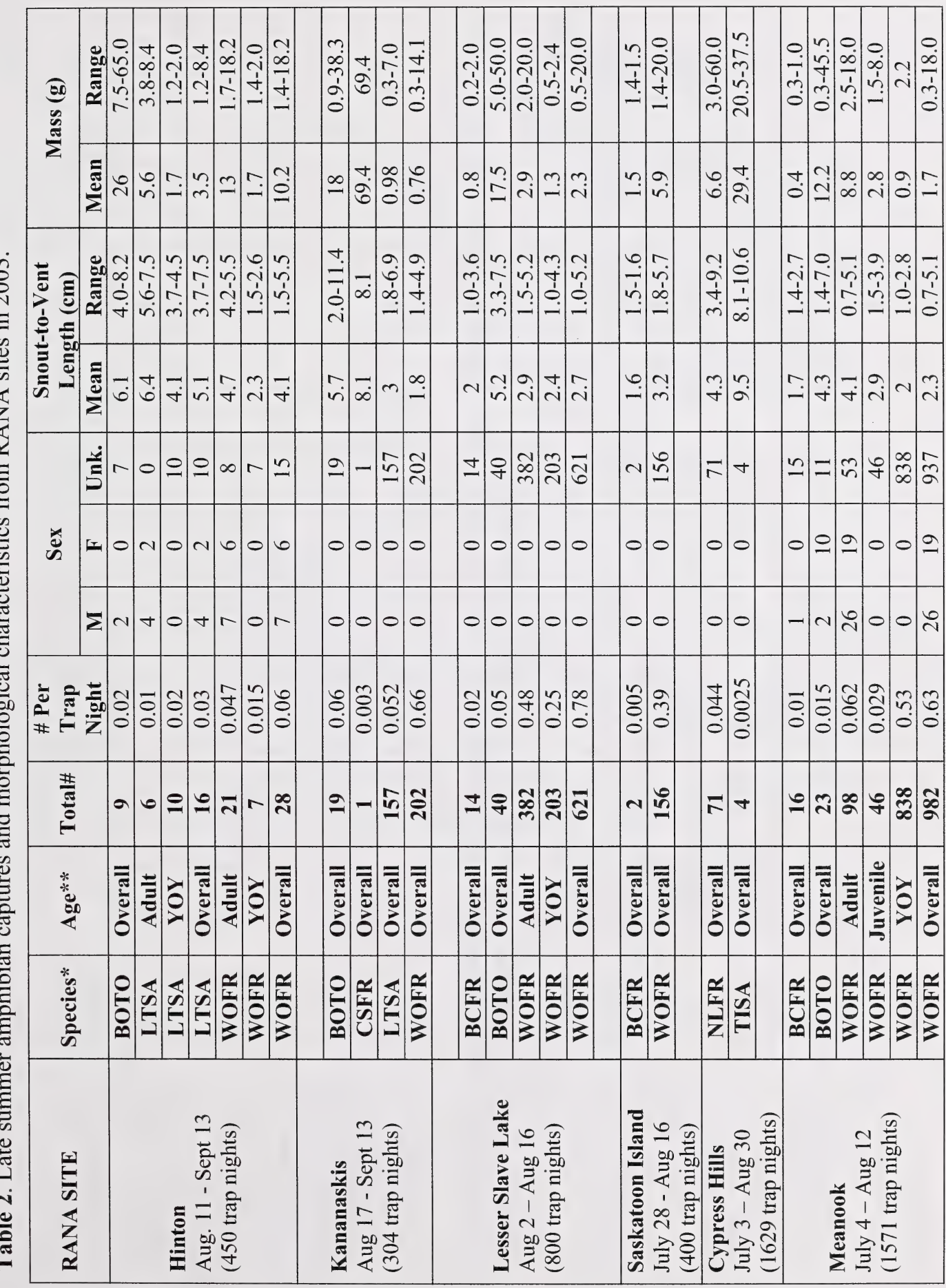




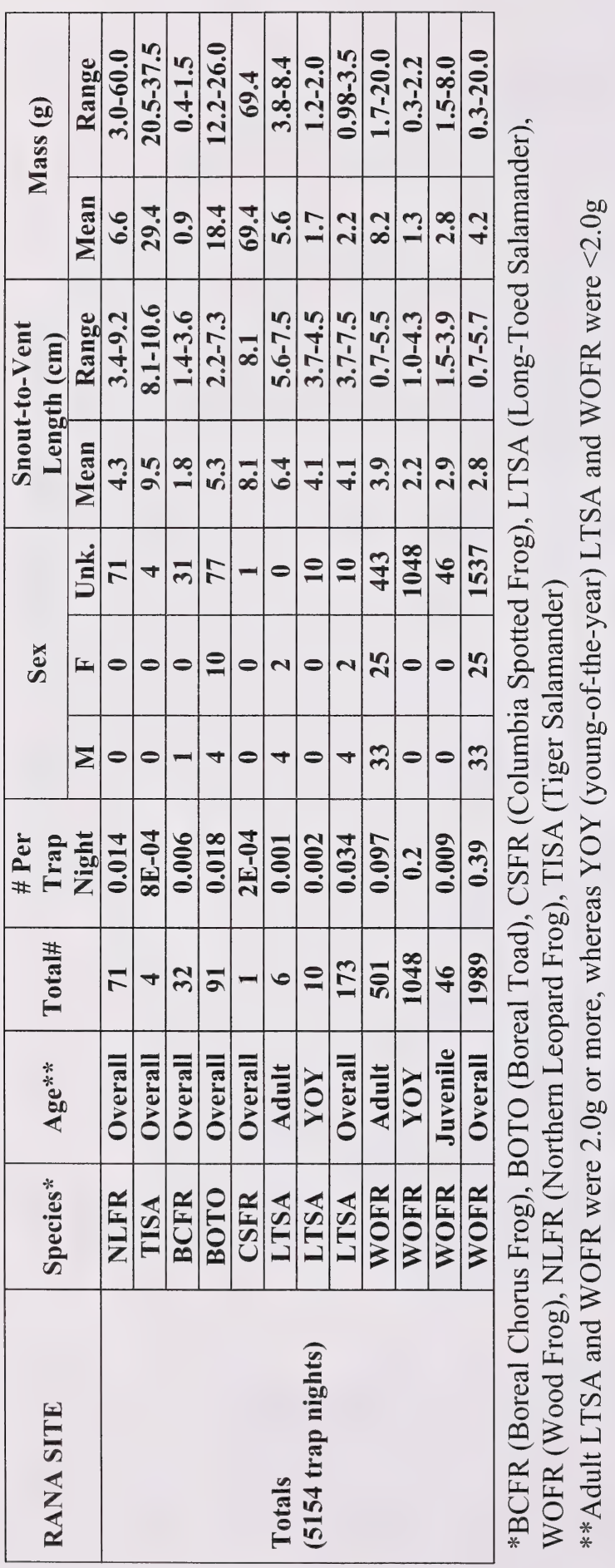




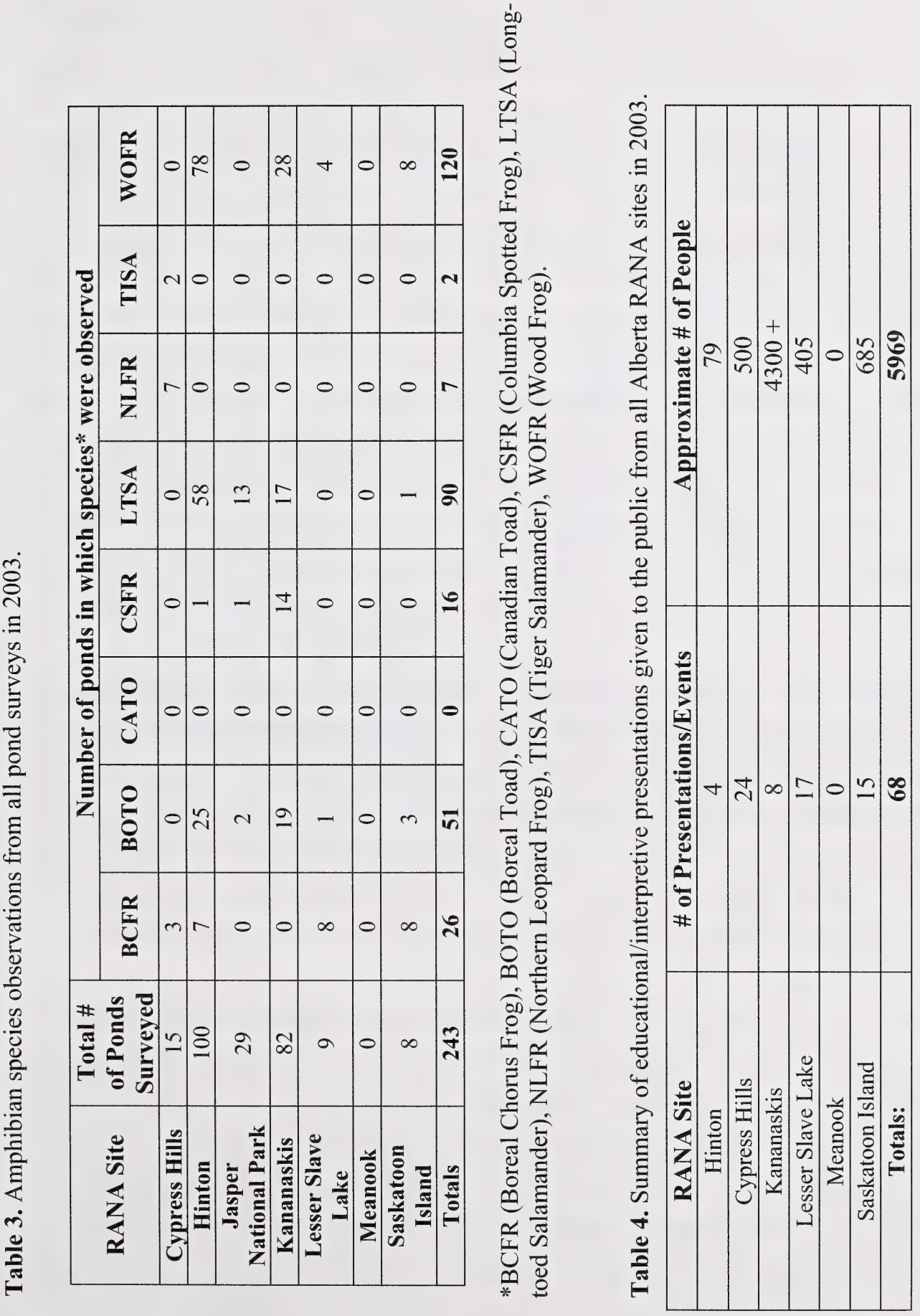




\subsection{DISCUSSION}

The types of species captured and observed at RANA sites in 2003 were consistent with data from previous years. Wood frogs continue to be the most ubiquitous species, being widely distributed across the province and the most abundant species captured. With the exception of Hinton, wood frog capture rates were higher than in all previous years. However, evidence of wood frog breeding was common in the Hinton area. The reason for the apparent population increase is unknown, but is not unexpected due to natural population fluctuations.

Long-toed salamander population persistence continues to be fairly stable in Hinton. Population persistence in Kananaskis is similar to last year, but relative to surveys in the mid-1990's, population persistence has gone down (refer to Wilkinson and Hanus 2003). Increased human activity and development may be contributing to this apparent reduction in breeding ponds. However, trapping data from the Kananaskis RANA pond, a relatively undisturbed site, suggest a healthy local breeding population. The Hinton site had unusually low numbers of young-of-the-year relative to the number of eggs laid, which may be a result of extremely low water levels at the trapping pond, contributing to increased competition and predation. Ongoing monitoring is needed to understand trends. Expanded surveys and reported observations from northwestern Alberta revealed the presence of long-toed salamanders near the town of Peace River, representing a range extension. In addition to observations near Fairview, there was an unconfirmed observation south of the Peace River. It is important to continue expanding surveys in northern Alberta to determine the range of the long-toed salamander population.

There were two captures of Columbia spotted frogs in 2003. Columbia spotted frogs are rarely encountered in the RANA program because they are found in the Rocky Mountains at higher elevations, where survey sites are under represented. Backcountry surveys and coordinated efforts with Parks are needed to effectively inventory Columbia spotted frogs. Boreal chorus frogs tend to be absent in the Rocky Mountains and uncommon in the foothills; however, they are usually at high numbers at Lesser Slave Lake. This was a below average year for boreal chorus frogs at Lesser Slave Lake, which may be due to the population explosion of wood frogs. Although boreal chorus frogs are a fairly common species, we lack information on their population trends and should not assume their populations are stable.

The boreal toad was the third-most abundant species captured in 2003, found in four of the six RANA sites. Capture rates were generally similar to previous years, recognizing that there have been considerable fluctuations between years. There is evidence of boreal toad population declines in other jurisdictions, so it is important to continue monitoring their population trends in Alberta. Similarly, it is important to expand survey efforts within Canadian toad range because there has been only one record throughout the history of the RANA program. The toad was captured in 1998 at Lesser Slave Lake, which is at the western edge of Canadian toad distribution in Alberta (the range is roughly limited to the eastern half of the province). Neither Meanook nor Beaverhill Lake RANA sites have recorded Canadian toads, despite being located in Canadian toad range. 
Northern leopard frogs were only observed in the Cypress Hills area, which is expected due to their known range. Given their current status as 'threatened' it is encouraging that there was evidence of breeding at the trapping pond. Pitfalls traps were successfully modified to be deeper and wider, improving capture efficiency. Seven of the 15 ponds surveyed at Cypress Hills had northern leopard frogs, of which five showed breeding activity. The number of tiger salamanders captured and observed in Cypress Hills was low, and as such was similar to previous years. Monitoring of a previously identified highway crossing of tiger salamanders west of Calgary did not yield any observations (other than wood frogs; Rose 2004). Surveys of nearby ponds and discussions with locals did not yield tiger salamander observations. Our understanding of tiger salamander mass movements is minimal, and it raises the question of whether heavily used roads pose a threat to migrating amphibians (see Rose 2004 for details).

Although the RANA program has operated for seven years, this is still a relatively short time period from which to draw conclusions about amphibian population trends due to their stochasticity. With improved consistency and continued monitoring we are beginning to generate an important long-term data set about amphibian distribution and population trends in Alberta. Currently, RANA data provide information on amphibian species presence and distribution, which also serve as a warning that a species may potentially be in decline due to its absence, or that certain breeding sites may be vulnerable. The data provide valuable information on timing of breeding as well as checking for possible deformities or disease. In addition, considerable life history information has been gathered. The variability in the numbers of species caught annually reinforces the need to conduct long-term monitoring.

Few amphibian species in Alberta are considered secure and wetland habitat is under threat of alteration or destruction. Maintenance of RANA sites, especially those sites in key habitats with long monitoring histories, is strongly recommended. Aside from amphibian monitoring, the RANA program provides extensive public education about amphibians and wetland conservation, which is arguably as important as monitoring. In recognition of global amphibian declines and national efforts to track amphibian population trends, Alberta's maintenance of the RANA program is critical.

\subsection{MANAGEMENT IMPLICATIONS AND FUTURE RESEARCH}

Management recommendations are limited given the relatively short period of time RANA has been operating. The primary recommendation is preservation of wetlands (i.e. prevent draining and contamination), particularly those known to have breeding populations of species at risk, and they should be carefully managed to ensure persistence of amphibian populations. Fish stocking can also have a detrimental effect on amphibians, particularly long-toed salamanders (refer to Rose 2004). We must balance the needs of amphibians with recreational activities. Minimizing potentially destructive activities around ponds is an additional consideration. On crown land, protective notations have been applied to create buffers around some breeding ponds. It is important to maintain communication with landowners and people who participate in activities around critical amphibian ponds in order to foster a sense of stewardship and appreciation for wetland ecosystems, and discourage collection of amphibians. Signage and education programs should be integrated with management activities. Future survey efforts should 
focus on northern Alberta and the Rocky Mountains, and consideration should be given to establishing long-term monitoring sites in the Parkland and Prairies. 


\subsection{LITERATURE CITED}

Alberta Environmental Protection. 1994. Natural Regions of Alberta: Summary. Alberta Environmental Protection. Edmonton, AB. 18 pp.

Alberta Sustainable Resource Development. 2000. The general status of Alberta wild species, 2000. Alberta Environment/Alberta Sustainable Resource Development. Edmonton, AB. 46 pp.

http://www3.gov.ab.ca/srd/fw/status/2000/2000 General Status_Species Rpt.pdf

Augustyn, T. 2004. Researching Amphibian Numbers in Alberta: Saskatoon Island Provincial Park, 2003 Field Summary. AB.

Hanus, S. and L. Wilkinson. 2004. Researching Amphibian Numbers in Alberta (RANA) Athabasca Valley Region - Hinton, Alberta, 2003 field summary. Alberta Conservation Association, Edmonton, AB.

Kempin, K. 2004. Researching Amphibian Numbers in Alberta: Lesser Slave Lake Provincial Park, 2003 Field Summary. Alberta Conservation Association.Edmonton, AB.

Kempin, K. 2004. Researching Amphibian Numbers in Alberta (RANA) Meanook Biological Research Station, Alberta, 2003 field summary. Alberta Sustainable Resource Development, Edmonton, AB.

Pretzlaw, T., M. Huynh, L. Takats, and L. Wilkinson. 2002. Protocol for monitoring long-toed salamander (Ambystoma macrodactylum) populations in Alberta. Alberta Species At Risk Report No. 35. Alberta Sustainable Resource Development. Edmonton, AB.

Rempel, J. 2004. Researching Amphibian Numbers in Alberta (RANA) Cypress Hills Provincial Park, Alberta, 2003 Field Summary.

Rose, S. 2004. Researching Amphibian Numbers in Alberta (RANA) Kananaskis Country and surrounding area, Alberta, 2003 Field Summary. Alberta Conservation Association. Edmonton, AB.

Wilkinson, L. and S. Hanus. 2003. Long-toed salamander conservation in the Alberta foothills; 2002 field summary. Alberta Species At Risk Report No.73. Alberta Sustainable Resource Development. Edmonton, AB. 


\subsection{APPENDICES}



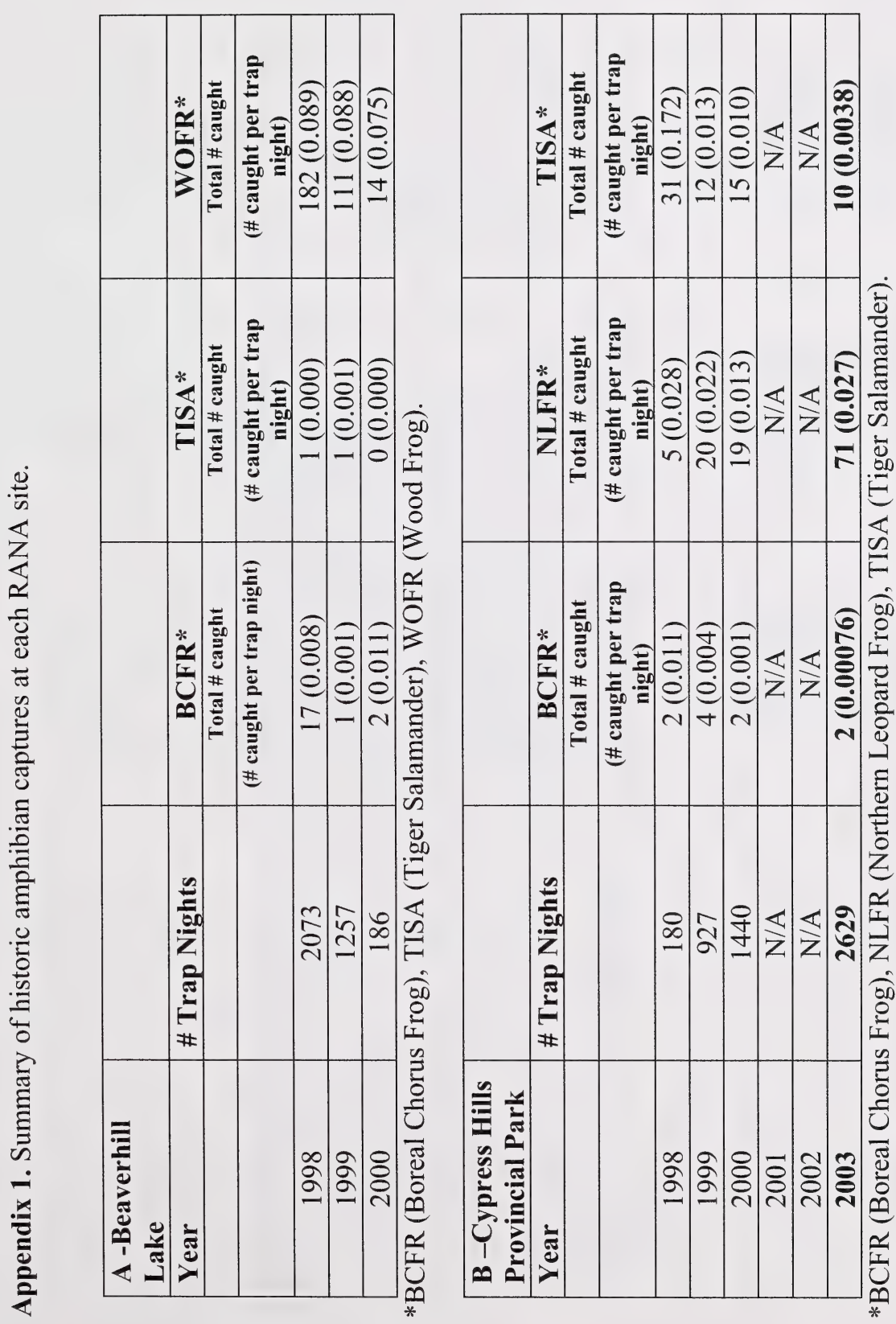

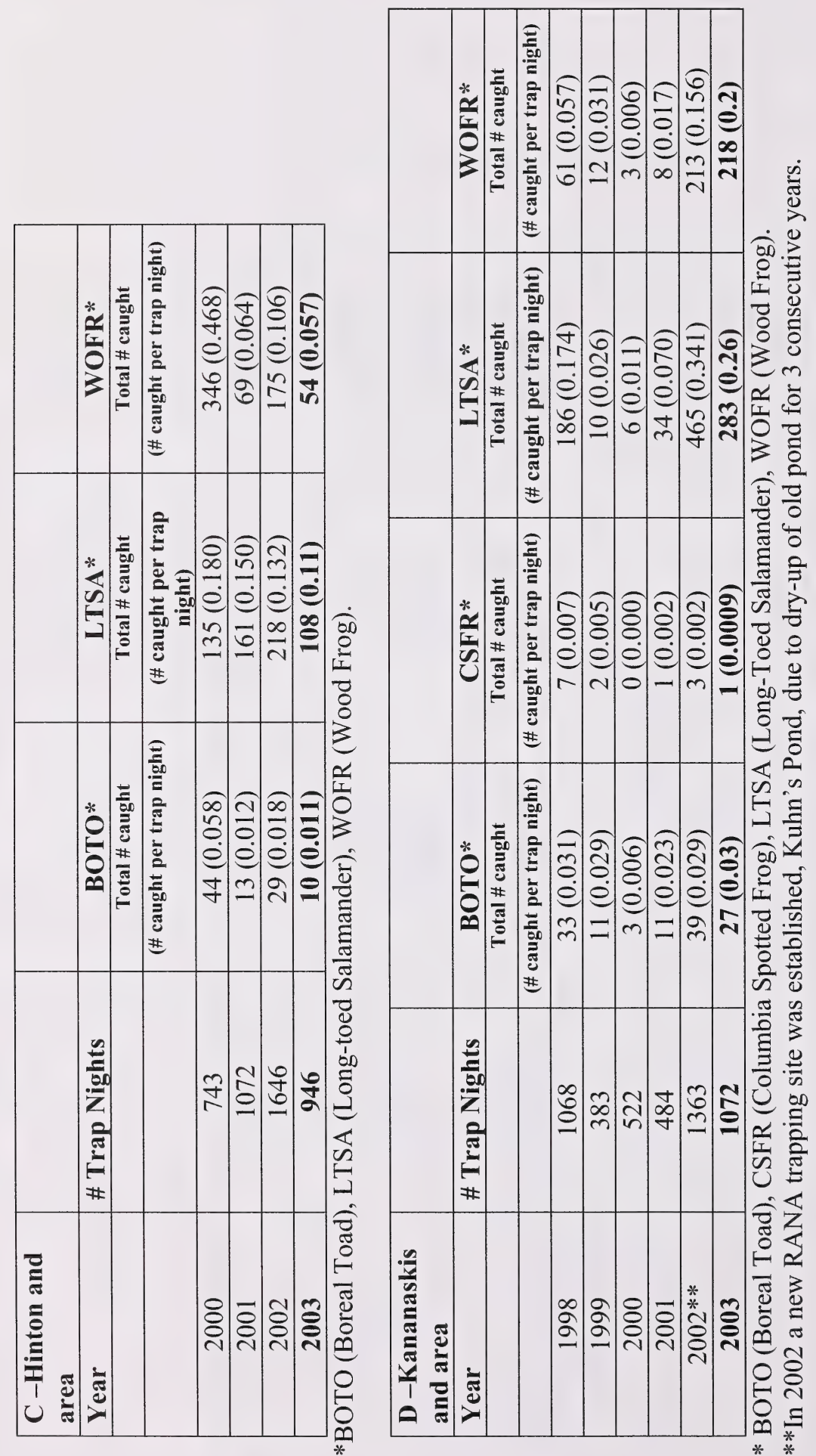


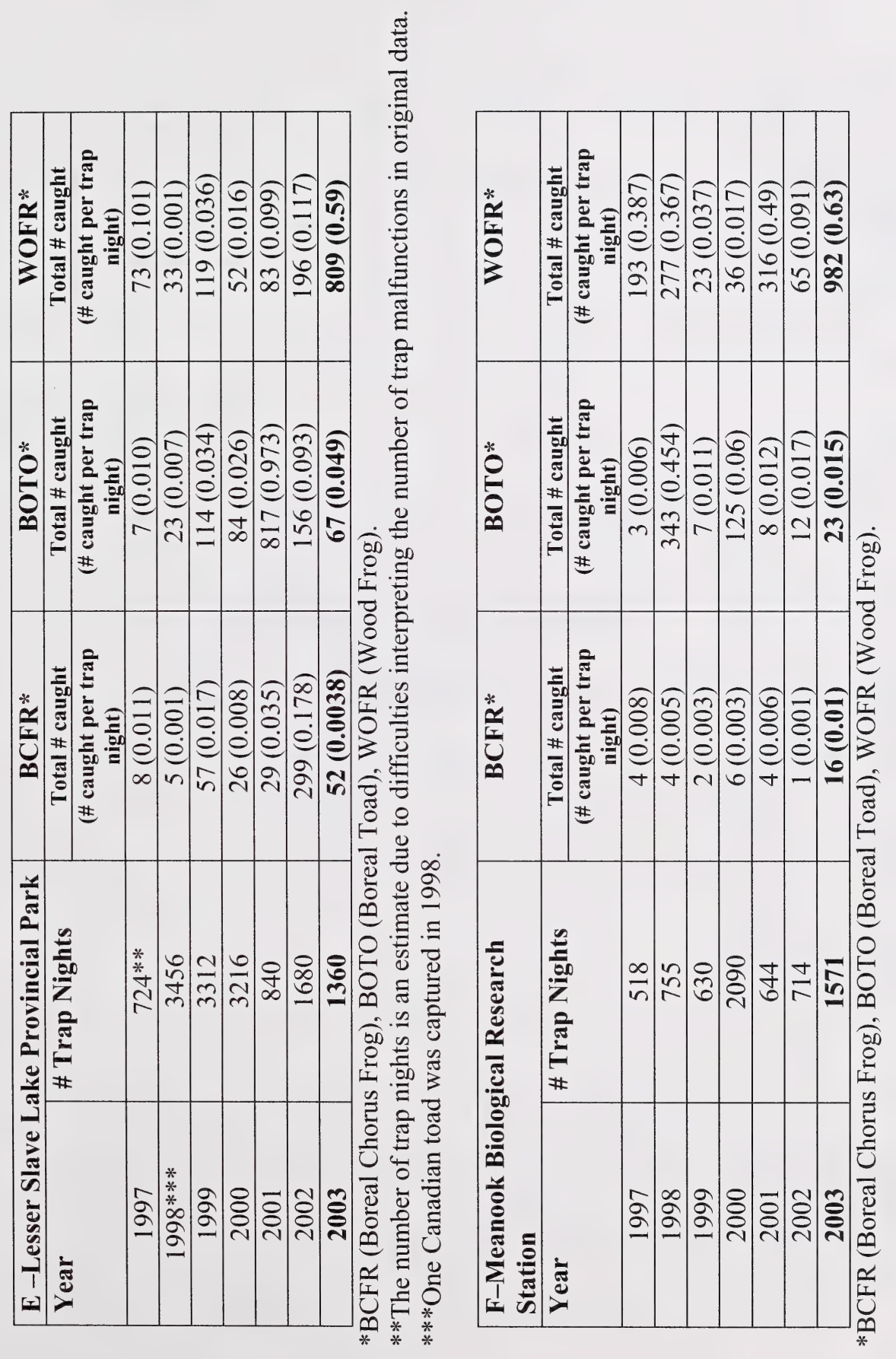




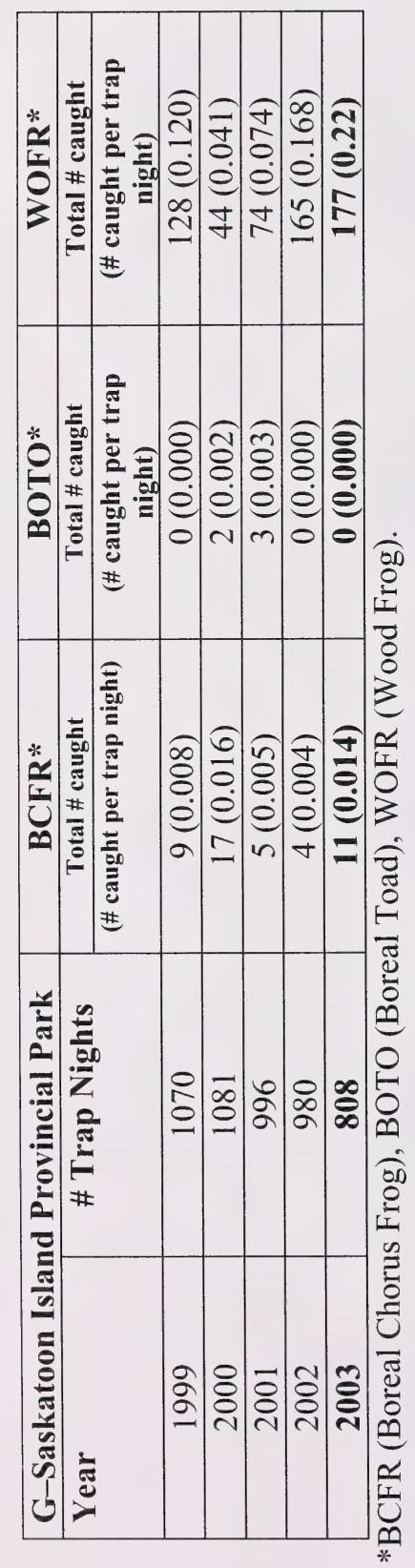




\section{List of Titles in This Series \\ (as of February 2004)}

No. 1. Alberta species at risk program and projects 2000-2001, by Alberta Sustainable Resource Development, Fish and Wildlife Division. (2001)

No. 2. Survey of the peregrine falcon (Falco peregrinus anatum) in Alberta, by R. Corrigan. (2001)

No. 3. Distribution and relative abundance of the shortjaw cisco (Coregonus zenithicus) in Alberta, by M. Steinhilber and L. Rhude. (2001)

No. 4. Survey of the bats of central and northwestern Alberta, by M.J. Vonhof and D. Hobson. (2001)

No. 5. 2000 survey of the Trumpeter Swan (Cygnus buccinator) in Alberta, by M.L. James and A. James. (2001)

No. 6. 2000/2001 Brassy Minnow inventory at Musreau Lake and outlet, by T. Ripley. (2001)

No. 7. Colonial nesting waterbird survey in the Northwest Boreal Region - 2000, by M. Hanneman and M. Heckbert. (2001)

No. 8. Burrowing owl trend block survey and monitoring - Brooks and Hanna areas, by D. Scobie and R. Russell. (2000)

No. 9. Survey of the Lake Sturgeon (Acipenser fulvescens) fishery on the South Saskatchewan River, Alberta (June-September, 2000), by L.A. Winkel. (2000)

No. 10. An evaluation of grizzly bear-human conflict in the Northwest Boreal Region of Alberta (19912000) and potential mitigation, by T. Augustyn. (2001)

No. 11. Harlequin duck monitoring in the Northern East Slopes of Alberta: 1998-2000 preliminary results, by J. Kneteman and A. Hubbs. (2000)

No. 12. Distribution of selected small mammals in Alberta, by L. Engley and M. Norton. (2001)

No. 13. Northern leopard frog reintroduction. Raven River - Year 2 (2000), by K. Kendell. (2001)

No. 14. Cumulative effects of watershed disturbances on fish communities in the Kakwa and Simonette watersheds. The Northern Watershed Project. Study 3 Progress report, by T. Thera and A. Wildeman. (2001)

No. 15. Harlequin duck research in Kananaskis Country in 2000, by C.M. Smith. (2001)

No. 16. Proposed monitoring plan for harlequin ducks in the Bow Region of Alberta, by C.M. Smith. (2001)

No. 17. Distribution and relative abundance of small mammals of the western plains of Alberta as determined from great horned owl pellets, by D. Schowalter. (2001)

No. 18. Western blue flag (Iris missouriensis) in Alberta: a census of naturally occurring populations for 2000 , by R. Ernst. (2000)

No. 19. Assessing chick survival of sage grouse in Canada, by C.L. Aldridge. (2000)

No. 20. Harlequin duck surveys of the Oldman River Basin in 2000, by D. Paton. (2000) 
No. 21. Proposed protocols for inventories of rare plants of the Grassland Natural Region, by C. Wallis. (2001)

No. 22. Utilization of airphoto interpretation to locate prairie rattlesnake (Crotalus viridis viridis) hibernacula in the South Saskatchewan River valley, by J. Nicholson and S. Rose. (2001)

No. 23. 2000/2001 Progress report on caribou research in west central Alberta, by T. Szkorupa. (2001)

No. 24. Census of swift fox (Vulpes velox) in Canada and Northern Montana: 2000-2001, by A. Moehrenschlager and C. Moehrenschlager. (2001)

No. 25. Population estimate and habitat associations of the long-billed curlew in Alberta, by E.J. Saunders. (2001)

No. 26 Aerial reconnaissance for piping plover habitat in east-central Alberta, May 2001, by D.R.C. Prescott. (2001)

No. 27. The 2001 international piping plover census in Alberta, by D.R.C. Prescott. (2001)

No. 28. Prairie rattlesnake (Crotalus viridis viridis) monitoring in Alberta - preliminary investigations (2000), by S.L. Rose. (2001)

No. 29. A survey of short-horned lizard (Phrynosoma hernandesi hernandesi) populations in Alberta, by J. James. (2001)

No. 30. Red-sided garter snake (Thamnophis sirtalis parietalis) education and relocation project - final report, by L. Takats. (2002)

No. 31. Alberta furbearer harvest data analysis, by K.G. Poole and G. Mowat. (2001)

No. 32. Measuring wolverine distribution and abundance in Alberta, by G. Mowat. (2001)

No. 33. Woodland caribou (Rangifer tarandus caribou) habitat classification in northeastern Alberta using remote sensing, by G.A. Sanchez-Azofeifa and R. Bechtel. (2001)

No. 34. Peregrine falcon surveys and monitoring in the Parkland Region of Alberta, 2001, by R. Corrigan. (2002)

No. 35. Protocol for monitoring long-toed salamander (Ambystoma macrodactylum) populations in Alberta, by T. Pretzlaw, M. Huynh, L. Takats and L. Wilkinson. (2002)

No. 36. Long-toed salamander (Ambystoma macrodactylum) monitoring study in Alberta: summary report 1998-2001, by M. Huynh, L. Takats and L. Wilkinson. (2002)

No. 37. Mountain plover habitat and population surveys in Alberta, 2001, by C. Wershler and C. Wallis. (2002)

No. 38. A census and recommendations for management for western blue flag (Iris missouriensis) in Alberta, by R. Ernst. (2002)

No. 39. Columbian mountain amphibian surveys, 2001, by D. Paton. (2002)

No. 40. Management and recovery strategies for the Lethbridge population of the prairie rattlesnake, by R. Ernst. (2002)

No. 41. Western (Aechmophorus occidentalis) and eared (Podiceps nigricollis) grebes of central Alberta: inventory, survey techniques and management concerns, by S. Hanus, H. Wollis and L. Wilkinson. (2002) 
No. 42. Northern leopard frog reintroduction - year 3 (2001), by K. Kendell. (2002)

No. 43. Survey protocol for the northern leopard frog, by K. Kendell. (2002)

No. 44. Alberta inventory for the northern leopard frog (2000-2001), by K. Kendell. (2002)

No. 45. Fish species at risk in the Milk and St. Mary drainages, by RL\&L Environmental Services Ltd. (2002)

No. 46. Survey of the loggerhead shrike in the southern aspen parkland region, 2000-2001, by H. Kiliaan and D.R.C. Prescott. (2002)

No. 47. Survey of native grassland butterflies in the Peace parkland region of northwestern Alberta - 2001, by M. Hervieux. (2002)

No. 48. Caribou range recovery in Alberta: 2001/02 pilot year, by T. Szkorupa. (2002)

No. 49. Peace parkland native grassland stewardship program 2001/02, by A. Baker. (2002)

No. 50. Carnivores and corridors in the Crowsnest Pass, by C. Chetkiewicz. (2002)

No. 51. 2001 Burrowing owl trend block survey and monitoring, Brooks and Hanna areas, by D. Scobie. (2002)

No. 52. An evaluation of the ferruginous hawk population in Alberta based on recent trend data, by D.P. Stepnisky, G.L. Erickson, J. Iwaasa and B. Taylor. (2002)

No. 53. Alberta amphibian call surveys. A pilot year. Final report, by L. Takats and C. Priestley. (2002)

No. 54. Utilization of a roadside survey technique to survey burrowing owl (Athene cunicularia hypugaea) in southeastern Alberta, by J. Nicholson and C. Skiftun. (2002)

No. 55. Alberta species at risk program and projects 2001-2002, by Alberta Sustainable Resource Development, Fish and Wildlife Division. (2002)

No. 56. Developing a habitat-based population viability model for greater sage-grouse in southeastern Alberta, by C.L. Aldridge. (2001)

No. 57. Peregrine falcon surveys and monitoring in the Northeast Boreal Region of Alberta, 2001, by R. Corrigan. (2002)

No. 58. 2002 burrowing owl trend block survey and monitoring, Brooks area, by R.F. Russell. (2002)

No. 59. Rare plant inventory of the eastern edge of the lower foothills natural subregion, west-central Alberta, by J. Doubt. (2002)

No. 60. Western (Aechmophorus occidentalis) and eared (Podiceps nigricollis) grebes of central Alberta: 2002 field summary, by S. Hanus, L. Wilkinson and H. Wollis. (2002)

No. 61. Inventory of western spiderwort (Tradescantia occidentalis) in Alberta: 2002, by S. Peters. (2003)

No. 62. Bullsnakes (Pituophis catenifer sayi) in Alberta: literature review and data compilation, by K.J. Kissner and J. Nicholson. (2003)

No. 63. Distribution of Ord's kangaroo rats in southeastern Alberta, by D.L. Gummer and S.E. Robertson. (2003)

No. 64. Lethbridge prairie rattlesnake conservation project: 2002/2003 progress report, by R.D. Ernst. (2003) 
No. 65. Short-horned lizard (Phrynosoma hernandesi hernandesi) populations in Alberta - 2002 survey results, by J.D. James. (2003)

No. 66. Inventory and monitoring protocol for naturally occurring western blue flag (Iris missouriensis) in Alberta, by R.D. Ernst. (2003)

No. 67. The use of call playbacks for censusing loggerhead shrikes in southern Alberta, by D.R.C. Prescott. (2003)

No. 68. Survey of bats in northeastern Alberta, by A. Hubbs and T. Schowalter. (2003)

No. 69. Survey protocol for the Richardson's ground squirrel, by B.A. Downey. (2003)

No. 70. Population estimates and a survey protocol for ferruginous hawks in Alberta, by B.N. Taylor. (2003)

No. 71. Testing methods for detecting wolverine, by G. Mowat, C. Kyle and D. Paetkau. (2003)

No. 72. A multi-species conservation strategy for species at risk in the Milk River basin: year 1 progress report, by R.W. Quinlan, B.A. Downey, B.N. Taylor, P.F. Jones and T.B. Clayton. (2003)

No. 73. Long-toed salamander (Ambystoma macrodactylum) conservation in the Alberta foothills: 2002 field summary report, by L. Wilkinson and S. Hanus. (2003)

No. 74. Researching Amphibian Numbers in Alberta (RANA): 2002 provincial summary, by L. Wilkinson and S. Hanus. (2003)

No. 75. Distribution and habitat associations of the long-toed salamander (Ambystoma macrodactylum) in the Oldman River drainage, by K. Pearson. (2003)

No. 76. Prairie rattlesnake (Crotalus viridis) hibernacula: monitoring history in Alberta 1987-2002, by K.J. Kissner and J. Nicholson. (2003)

No. 75 Distribution and habitat associations of the long-toed salamander (Ambystoma macrodactylum) in the Oldman River drainage, by K. Pearson. (2003)

No. 76 Prairie rattlesnake (Crotalus viridis) hibernacula: monitoring history in Alberta 1987-2002, by K.J. Kissner and J. Nicholson. (2003)

No. 77 Alberta species at risk program and projects 2002-2003, by Alberta Sustainable Resource Development, Fish and Wildlife Division. (2003)

No. 78 Northern leopard frog reintroduction: Year 4 (2002), by K. Kendell. (2003)

No. 79 Magrath Northern Leopard Frog Reintroduction Project - Year 1 Progress Report, by K.A. Romanchuck. (2003)

No. 80 Conservation Overview of Butterflies in the Southern Headwaters at Risk Project (SHARP) Area, by N. Kondla. (2004)

No. 81 Lethbridge Rattlesnake Conservation Project: 2003 Progress Report, by R. Ernst. (2004)

No. 82 Shortjaw Cisco Species at Risk Assessment 2001, by M. Steinhilber. (2004)

No. 83 Researching Amphibian Numbers in Alberta (RANA): 2003 provincial summary, by L. Wilkinson and K. Kempin. (2004) 



